could possibly have been penned on his book, so far as the omission of such substances as the Calabar bean, carbolic acid, pepsine, veratrum viride, cerium and its salts, actæa racemosa, bromide of ammonium, \&c., is concerned. The omission of all these, except the bean, and of that in its proper place, does not however call for such grave remark as the extreme meagreness and inaccuracy of the few lines "smuggled in." Not to speak of the important constitutional action of the Calabar bean on the nervous system, it must be observed that mydriasis is not a disease at all, but a symptom of many and various diseases; that the local uses of Calabar bean are not confined to the treatment of mydriasis; and that these are here most inaccurately and incompletely described.

\section{DR. COPLAND'S DICTIONARY.}

\section{To the Editor of THE LANCET.}

Srr, - I was much interested in the perusal of Dr. Copland's letter in your journal of the 2nd inst. on the subject of the cattle plague. Living as I do in the midst, or rather on the edge, of one of the most infected districts in the country, my thoughts and attention have been necessarily much directed to this pestilence; and the result of all that $I$ have seen and heard and read upon the subject, has been to impress my mind very strongly with the belief that the disease, if not actually erysipelas, attacking the mucous membranes, partake largely of an erysipelatous character. Carrying out this train of thought, it appeared to me that the same mode of treatment which we adopt in erysipelas, as seen in our practice, ought to have some marked effect upon the cattle disease, as viewed in this light. I therefore suggested three weeks ago to $\mathrm{Mr}$ Secker, the very talented and distinguished veterinary surgeon, who lives in this immediate neighbourhood (at Knaresborough), the propriety of giving a fair trial to a remedy which has, I believe, more than any other, a specific virtue in erysipelas-viz., the tincture of sesquichloride of iron; and that the use of this remedy should be combined with that of hydrochloric acid, or chlorate of potass, or both, according to the nature and requirements of each individual case, but making the sesquichloride of iron the basis of the medicinal treatment; of course attending at the same time vory carefully to the important points of keeping up the circulation on the surface and at the extremities, supplying such food and in such quantitie as the animal will bear. Three weeks (I beliere to-day) har now elapsed since Mr. Secker began to try this plan of treatment; and I am happy in being able to state, as his opinion, that it has exceeded all his expectations, and that he considers it by much the most encouraging mode of treating this disease that he has met with, or tried. The position of Mr. Secker, as having one of the largest practices in the country, and as being a member of the Council of the Veterinary College, stamps a high value upon this opinion, and I trust that the veterinar profession throughout the country will give this treatment a fair trial. I am rejoiced to see that Dr. Copland, in his letter to THE LANCET above alluded to, has suggested a somewhat similar mode of treatment, although he has not had the opportunity of testifying to its satisfactory results. I may venture to add, however, that the dose (one drachm of tincture of the susquichloride of iron twice or three times a day) which Dr. Copland recommends falls very far short of that which Mr. Secker uses. He gives, in divided doses, one ounce in twenty-four hours.

Before concluding this letter, will you permit me to say one word to the homoopaths (fas est ab hoste doceri). They vaunt very largely and very loudly the prophylactic effects of arsenic. Let them prepare a beast for a fortnight with their second, third, or twentieth solution of arsenicum; then let them place it in a byre with three or four diseased cattle. If this victim (!) escapes the disease, let them make the same experiment with two other beasts, and, if they all escape, the public will feel that the homoopaths have made out a strons case. Anything short of this cannot be deemed satisfactory and to sing, as they do, an Io triumphe over the immunity from the disease of beasts which have taken this solution and have not had the rinderpest, is as unphilosophical as, in my humble opinion, is the rest of their creed.

I am, Sir, your obedient servant George Kennion, M.D., F.R.C.P. (Elect.)

Oa: Lee, Harrogate, Dec. 4th, 186 ŏ $^{2}$

\section{REFORM AT THE COLLEGE OF SURGEONS.}

THE remarkable tenacity with which the College of Surgeons, adheres to its old and bad ways is among the most prominent of its peculiarities. All the influence of Brodie, and all the eloquence of Green, could not change the settled purpose of the banded monopolists. There sit on the Council ten men, always enjoying incomes from the College estimated at $£ 400$ or $£ 500$ a year each. They have direct personal interest in maintaining possession of that profit. It is true that the examiners of the College are, as a body, and by necessity, from the mode and period of their election, and from the protraction of their term of office, the most inefficient examiners in the world. It is true that the incompleteness of the examination, the superannuated antiquity of the examiners, their ignorance of some of the most important modern additions to medical and surgical knowledge, their number, their costliness, the short time given to their work, and the slovenly system on which it is founded, are notorious to the world, and shame the College. But they are there. They vote on the Council; they dangle the promise of the next seats before the two or three next in rotation, and by one means or another secure a practical majority on all questions affecting themselves directly or indirectly. They will hardly acknowledge it, even, perhaps, to themselves; for the reasons on which men act, and those which they formally recognise, often differ very much. But the true reason why the Court of Examiners throws its influence into the scale against voting by proxy is because it indirectly affects themselves. Thus they have this week rejected the memorial of the British Association for voting papers for the country Fellows. They fear to have the charter touched. They know that there are real abuses perpetuated under it, of which their present constitution is one of the worst, and they will rather see any wrong done to others than contemplate the disturbance of their sacred abuses. This is the real meaning of the constant obstruction of any recommended change. If the Fellows and Members really desire now to reform the College, it is evident that the impulse must come from without. The Council will not reform themselves, and the body without must apply to Sir George Grey for such alterations in the charter as are thought necessary. We warn the Council that they will force this proceeding upon the profession, and that the changes so made will be less agreeable to them than if issuing from their own chamber.

\section{DR. CLAY AND MR. SPENCER WELLS.}

THe controversy between these two gentlemen, with the subject-matter of which our readers are already familiar, has been very properly submitted to professional arbitration. The following is the award :-

"We, the undersigned, being the arbitrators nominated re. spectively by Mr. T. Spencer Wells and Dr. Clay, and appointed under Judge's order, dated June 29, 1865, have, in consultation, examined and considered the publications com. plained of by Mr. Wells as being libellous against him, and the documents bearing on the matter.

"Before entering upon this investigation, we, in compliance with the terms of the Judge's order, obtained the assent of James Paget, Esq., F.R.C.S., to act as umpire in the event of our differing in judgment.

"Having fully considered the matter referred to us, we are of opinion that the defendant, Dr. Clay, has exceeded the bounds of fair criticism in the publications complained of, and that he ought to make an apology to Mr. Wells in the following terms :-

"I, Charles Clay, M.D., defendant in the case of Wells $v$. Clay, acknowledge that in the statement and inferences con tained in an article published by me in The LANCET of February 25,1865 , I exceeded the bounds of fair criticism. I especially admit that $I$ was not justified in putting forth the following paragraph, which contains the passages complained of by Mr. Wells :- 
" ' In this case Mr. Wells did not misrepresent my diagnosis, but did worse: he knew it, as well as those that were with him, but he omitted it altogether. My opinion was this: 'On no account seek any operation. If ever I saw malignant disease, this is a case, and, if operated upon, must terminate speedily in death.' I was earnestly pressed to operate, but, though a splendid fee would have resulted, I persevered in my refusal, and the fee went into Mr. Wells's pocket. I never regretted my portion of the transaction. I never will operate on a case decidedly hopeless. I will have a prospect of success before I begin, and no fee shall ever tempt me without such prospect in view. In this case Mr. Wells held out hopes from an operation. It was done, and she died in a few hours after."

"I am now satisfied that Mr. Wells did not know my opinion respecting the case, nor that $I$ had refused to operate, and that, therefore, the imputation that he had improperly suppressed my opinion is groundless. I freely admit that Mr. Wells was induced to operate believing that there was a reasonable prospect of success, and that he was quite justified in forming that opinion. Further, if the words I used seem to imply that Mr. Wells's object in operating was to obtain a fee, I assure him that they were not intended to bear that meaning, and I am very sorry that I used language which could be so interpreted. Finally, I hereby express my conviction that Mr. Wells behaved throughout in an honourable manner to the patient, her family, and medical attendants, and in all respects in accordance with the rules of professional etiquette and right conduct ; and I now make this statement intending it to be a full retractation of the matter complained of, and trusting that $\mathrm{Mr}$. Wells will accept it as an ample apology for my exror.

November, 22nd, 1865."

On Dec. 5th Dr. Clay signed this apology.

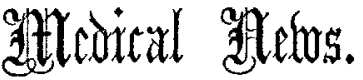

Apothecaries' HaLL. - The following gentlemen passed their examination in the Science and Practice of Medicine, and received certificates to practise, on the 7 th inst. :-

Davies, John, Wrexham.

Denne, Henry, Sandwich, Kent.

Prince, John, Staines.

Simpson Reginald Palorave, Torrington-street.

Tindall, Alexander 2I'Ivor, Falsgrave, Scarborough.

The following gentlemen also on the same day passed their first examination:-

Anderson, Robert, St. George's IIospital.

Cornish, Edgcumbe, University College.

Melhado, Alfred Courtnay B., St. Bartholomew's Hospital.

Owens, Edward Matthew, Guy's Hospital.

Ring, Edmund Cuthbert, St. George's Hospital.

Smith, Samuel Hignett, King's College.

Williams, William Edwin, St. Bartholomew's Hospital.

The late King of the Belgians.-The death of King Leopold, often threatened, and averted by signal exertion of skill and care, has plunged Europe into grief. The late King suffered severely from disease of the heart, with pulmonary obstruction, bronchitis, anasarca, \&c. By the skill of Mr. Henry Thompson he was happily and entirely relieved from the pressing sufferings caused by the presence of a stone in the bladder, which some of the most distinguished surgeons in Europe failed to remove. No recurrence of these symptoms ever took place. Besides the constant and devoted attentions of Dr. Koepl and the Belgian physicians, the King owed much to the great skill and eare of Dr. Jenner. His obligations to Dr. Jenner and Mr. Thompson were fully appreciated by the royal patient ; both were rewarded by orders of knighthood, and received marks of most gracious kindness and regard.

Bethlenen Hospital. - The governors of this institution have been in somewhat of a fix respecting the qualification to be posssesed by their resident physician. The old rule required that he should be a Fellow or Licentiate of the College of Physicians in London, Edinburgh, or Dublin, or a Doctor of Medicine of the University of Oxford, Cambridge, or Edinburgh, qualified to practise as a physician. It will be seen at once that this rule disqualifies a large class of the besteducated practitioners. Thanks to Dr. Webster, the following rule has been adopted by the committee of the hospital :-_" There shall be a resident physician, who must be a Doctor of Medicine of an university in the United Kingdom, and a Fellow or Member of the College of Physicians in London, Edinburgh, or Dublin, qualitied to practise as a physician."
Charter House. - We are happy to observe that Dr. Robert Fowler is a candidate for the vacancy created by the retirement of Mr. Miles. That gentleman is well and favourably known to the profession by his very useful Medical Lexicon, a work displaying sound acquirements and great industry. His professional qualifications also are of the most sterling kind.

A Medical Sorrex-Mr. Baker Brown, the President of the Medical Society of London, gave a soirée on Tuesday last, at the Hanover-square Rooms, to the Fellows of this Society. Ladies also were invited. The result was of so satisfactory a kind that we shall not regret to see the example set by Mr. Brown followed. Nearly 500 persons assembled in the rooms. A very brilliant display was made of scientific objects, microscopes, jewels, works of art, statuary, photographs, rare birds, choice china, and articles of vertu. It is only due to those gentlemen who added to the interest of the evening by their various contributions to mention their names. They are as follow :-Mr. Joseph, of Bond-street; Mr. Benson, of Old Bond-street; Mr. Harry Emanuel ; Messrs. Savory and Moore; Messrs. Piesse and Lubin; Mr. H. Ward ; Mr. Ernest Edwards; Messrs. Wirth, Brothers; Mr. Henry Swan; Messrs. W. H. Buck and Co.; The London Stereoscopic Company; Messrs. Sharpe and Cullam; Messrs. Day and Co.; Mr. Robert Crofts; Messrs. Cramer and Co.; Messrs. Watherston and Sons; Mr. Collins; Mr. Pillischer; Messrs. Whicker and Blaise; Mr. Pratt; Mr. Ladd; Mr. Lockhart Clarke ; Dr. Gibb; Dr. Thudichum; Mr. Smallcombe. The soirée was of a far more agreeable and interesting character than such social gatherings have been hitherto when confined to gentlemen alone. And whatever doubts may have prevailed as to the probable effect of this innovation, they must be dispelled by its complete success.

Syphinization.-Prof. Boeck is about to return home after a stay of four months in London, during which he has practised inoculation as a method of cure on a series of syphilitic patients under the care of Mr. James Lane at the Lock Hospital. At the meeting of the Medical Society of London, George-street, Hanover-square, on Monday next, at eight o'clock, Mr. James Lane will read a paper descriptive of the results obtained up to the present time, and Prof. Boeck will be present on the occasion.

The Ulster Medical Society.-The anniversary dinner of this influential provincial Society of medical practitioners took place on the 7th inst., at Thompson's Rooms, Donegall-place, Belfast. A very pleasant evening was passed, and the usual loyal and other toasts given.

Mr. Walter Rivington, F.R.C.S. Eng., \&c., has just been presented by several students at the London Hospital with a handsome clock, " in grateful appreciation and remembrance of his services as Demonstrator of Anatomy during the winter session of $1864-5$."

Andersonian Medical Socrety, Glasgow.-The following gentlemen have been elected office-bearers for session 1865-6:- President: Dr. J. G. Wilson. Vice-President: Mr. Samuel Woodcock. Secretaries: Messrs. W. Dove Macfarlane and Robert Colquhoun. Treasurer : Mr. W. Easby. Librarians: Messrs. A. C. Moffat and J. H. Hill. Auditors: Messrs. James Robinson and J. T. D. Hughes.

IN Memoriam. - The professional associates of the late Dr. Bickersteth have gracefully paid their tribute to his memory by placing a tablet in the vestibule of Somerset Hospital, commemorative of his distinguished talents and eminence as a physician. Dr. Bickersteth's celebrity was not confined to the Colony, and we believe that thousands, in all parts of the world, who benefited by his counsel will endorse the words in the inscription, that "in his death medical science and the public sustained a grievous loss." The tablet is of the purest marble, and bears the following inscription :-

$$
\text { In Memoriam }
$$

Henrici Bickersteth, M.D., F.R.C.S. Chirurgi Nosocomii Somerset

hune lapidem

ocii illius Medici statuunt

famam ejus celebrem,

dotesque insignes, admirantes et collaudantes.

Mors ejus et medicæ

arti et populo, magno damno fuit.

E vita excessit

die vi. Augusti, mdecclxii. 